\title{
DOES SEVERE OBESITY EFFECT EARLY POSTOPERATIVE RECOVERY AND SURGICAL OUTCOMES IN PATIENTS UNDERGOING PERCUTANEOUS NEPHROLITHOTOMY UNDER SPINAL ANESTHESIA?
}

\author{
AĞIR OBEZITE HASTALARIN SPINAL ANESTEZI ALTINDA PERKÜTAN NEFROLITITOMI \\ UYGULANMASI POSTOPERATIF ERKEN DÖNEM IYILEŞME VE CERRAHI \\ SONUÇLARINI ETKILER MI?
}

\author{
Ahmed Ömer HALAT ${ }^{1}$ (D), Muhammet irfan DÖNMEZ² (D), Murat GÖNEN ${ }^{1}$ (D), Ömer Erkam ARSLAN ${ }^{3}$ (D), Betül BAŞARAN ${ }^{4}$ \\ 'University of Health Sciences, Konya Training and Research Hospital, Clinic of Urology, Konya, Turkey \\ ${ }^{2}$ Istanbul University, Istanbul Faculty of Medicine, Department of Urology, Istanbul, Turkey \\ ${ }^{3}$ Antalya Kepez State Hospital, Clinic of Urology, Antalya, Turkey \\ ${ }^{4}$ University of Health Sciences, Konya Training and Research Hospital, Anestezi ve Reanimasyon, Konya, Turkey
}

ORCID IDs of the authors: A.Ö.H. 0000-0003-4434-9274; M.I.D. 0000-0002-2828-7942; M.G. 0000-0001-7994-8790;

Ö.E.A. 0000-0002-8849-5567; B.B. 0000-0001-5994-3861

Cite this article as: Halat AO, Donmez MI, Gonen M, Arslan OE, Basaran B. Does severe obesity effect early postoperative recovery and surgical outcomes in patients undergoing PNL under spinal anesthesia? J Ist Faculty Med 2021;84(3):354-9. doi: 10.26650/IUITFD.2021.839546

\section{ABSTRACT}

Objective: The primary aim of this study is to evaluate if severe obesity has any deleterious effect on the early postoperative course in patients undergoing percutaneous nephrolithotomy (PNL) under spinal anesthesia, and the secondary aim is to determine whether severe obesity changes surgical results.

Material and Method: The study included 100 patients who underwent a PNL operation for kidney stones of $\geq 2 \mathrm{~cm}$ in our clinic. Accordingly, those with $\mathrm{BMl}<35 \mathrm{~kg} / \mathrm{m}^{2}$ formed the first while the severely obese $\mathrm{BMI} \geq 35 \mathrm{~kg} / \mathrm{m}^{2}$ formed the second group. Age, gender, stone burden, pre/postoperative hemoglobin levels, number and regions of access, duration of surgery, perioperative complications and Visual Analogue Scale score at 24h, PACU admission/ discharge Aldrete scores, and PACU length of stay were recorded.

Results: The VAS score was $5.0 \pm 1.3$ in group 1 while it was $5.3 \pm 1.8$ in group $2(p=0.32)$. The length of the hospital stay was $3.3 \pm 1.3$ days in patients with $\mathrm{BMl}<35 \mathrm{~kg} / \mathrm{m}^{2}$ and $3.0 \pm 1.0$ in patients with $B M I \geq 35 \mathrm{~kg} / \mathrm{m}^{2}(p=0.36)$. A $98 \%$ stone-free rate was found in the severely obese group and $96 \%$ in the normal BMI group, and there was no significant difference between the groups $(p=0.672)$. There was a statistically significant difference in terms of PACU discharge Aldrete scores between groups

\section{ÖZET}

Amaç: Bu çalışmanın birincil amacı, spinal anestezi altında perkütan nefrolititomi (PNL) uygulanan hastalarda ağır obezitenin erken postoperatif seyir üzerinde zararlı bir etkisinin olup olmadığını değerlendirmektir. İkinci olarak, ağır obezitenin cerrahi sonuçları değiştirip değiştirmediğini belirlemektir.

Gereç ve Yöntem: Çalışmaya kliniğimizde $\geq 2 \mathrm{~cm}$ böbrek taşı nedeniyle PNL operasyonu yapılan 100 hasta dahil edildi. Buna göre birinci grupta $\mathrm{VKi}<35 \mathrm{~kg} / \mathrm{m}^{2}$ olanlar, ikinci grupta ise ciddi derecede obez $\mathrm{BKI} \geq 35 \mathrm{~kg} / \mathrm{m}^{2}$ olanlar oluşturuldu. Yaş, cinsiyet, taş yükü, ameliyat öncesi/sonrası hemoglobin seviyeleri, giriş sayısı ve bölgeleri, ameliyat süresi, perioperatif komplikasyonlar ve 24. saatte Görsel Analog Skala skoru, PACU yatış/taburculuk Aldrete skorları ve PACU kalış süresi kaydedildi.

Bulgular: Grup 1'de VAS puanı 5,0 $\pm 1,3$ iken grup 2'de 5,3 $\pm 1,8$ idi $(p=0,32)$. Hastanede kalış süresi VKi $<35 \mathrm{~kg} / \mathrm{m}^{2}$ olan hastalarda $3,3 \pm 1,3$ gün, $V K i \geq 35 \mathrm{~kg} / \mathrm{m}^{2}$ olan hastalarda $3,0 \pm 1,0$ idi $(p=0,36)$. Ağır obez grupta \%98, normal vücut kitle indeksi grubunda \%96 taşsızlık oranı saptandı ve gruplar arasında anlamlı fark yoktu $(p=0,672)$. Gruplar arasında PACU taburcu Aldrete skorları açısından istatistiksel olarak anlamlı fark vardı (Grup 1 ve

Corresponding author/iletişim kurulacak yazar: ahmed-halat@hotmail.com

Submitted/Başvuru: 15.11.2020 • Revision Requested/Revizyon Talebi: 03.02.2021 •

Last Revision Received/Son Revizyon: 21.02.2021 • Accepted/Kabul: 23.02.2021 • Published Online/Online Yayın: 12.07 .2021 
(9.9 \pm 0.3 vs. $9.6 \pm 0.4$ in groups 1 and 2 , respectively) ( $p=0.03$ ). Finally, the time interval in PACU was $39.0 \pm 7.5$ mins in group 1 while it was $58.8 \pm 14.0$ mins in group $2(p<0.0001)$.

Conclusions: Severe obesity does not alter surgical outcomes in patients undergoing PNL under spinal anesthesia, and in our opinion, spinal anesthesia in PNL is a safe and effective anesthesia modality for renal stone(s) in obese and morbidly obese patients.

Keywords: obesity, PACU, PNL, spinal anesthesia, prospective
2 'de sırasıyla $9,9 \pm 0,3$ ve $9,6 \pm 0,4)(p=0,03)$. Son olarak PACU'da zaman aralığı grup 1 'de $39,0 \pm 7,5$ dk iken grup 2'de $58,8 \pm 14,0$ dk idi $(p<0,0001)$.

Sonuç: Şiddetli obezite, spinal anestezi altında PNL uygulanan hastalarda cerrahi sonuçları değiştirmez ve bize göre PNL'de spinal anestezi, obez ve morbid obez hastalarda renal taş(lar) için güvenli ve etkili bir anestezi yöntemidir.

Anahtar Kelimeler: obezite, PACU, PNL, spinal anestezi, prospektif

\section{INTRODUCTION}

Obesity is a major worldwide health problem, and nowadays, as a result of a sedentary lifestyle, decreased physical activity, and high-fat diet, the number of obese individuals has rapidly increased in both developed and developing countries (1, 2). Although no single etiology is known to be fully responsible for the association between obesity and urolithiasis, with increasing BMI, metabolic disorders such as hypercalciuria, hyperoxaluria, hyperinsulinemia, and low urine volume may be contributing factors in patients with metabolic syndromes (3). Because of all these, obese patients are more likely to be faced with a renal stone disease (4). Consequently, it can be considered that urologists everywhere will encounter obese patients with kidney stones more frequently.

Currently, many treatment methods to eliminate renal stones are available, including extracorporeal shock wave lithotripsy (SWL), flexible ureterorenoscopy (f-URS), and percutaneous nephrolithotomy (PNL). Due to technical reasons such as thicker skin and subcutaneous tissue in obese patients, the inability to obtain clear images under fluoroscopy, and the incompatibility with a SWL table, SWL is insufficient for most cases, especially on large stones (5). The effectiveness of f-URS on kidney stones smaller than $2 \mathrm{~cm}$ in size has been shown in obese patients, but the need for multiple interventions as the stone size increases is an significant disadvantage $(6,7)$. Recently, PNL remains one of the most important treatment options for renal stone treatment (4).

Percutaneous nephrolithotomy is an effective minimally invasive surgical treatment method that is generally applied under general anesthesia in the treatment of large, multiple, and complex stones in the upper urinary system (8). On the other hand, many studies conducted in recent years have shown that regional anesthesia can be performed safely and effectively in patients undergoing PNL $(9,10)$. However, data regarding PNL under spinal anesthesia in obese patients is limited.

The primary aim of this comparative prospective study is to evaluate if severe obesity has any deleterious effect on the early postoperative course in patients undergoing
PNL under spinal anesthesia. Secondly, it is to determine whether severe obesity changes surgical results.

Complications related to the respiratory tract during and after operations are more common in obese patients due to general anesthesia and may show a destructive course. In addition, patients can more easily tolerate the common pain problems after surgery with spinal anesthesia, and their analgesic needs are reduced. For the anesthesiologist, the separation of obese patients from postoperative positive pressure ventilators is quite challenging, and it requires great effort to provide spontaneous breathing $(9,10)$. Considering all this, we think that the prevention of complications due to general anesthesia that may be encountered during early postoperative period will increase the surgical success by all means.

\section{MATERIAL AND METHOD}

Patients undergoing PNL were prospectively included between May 2017 and November 2017 for this study that took place in the Urology Clinic of Health Sciences University Konya Training and Research Hospital. The patients were divided into 2 groups according to their body mass index (BMI). Accordingly, those with $\mathrm{BMl}<35 \mathrm{~kg} / \mathrm{m}^{2}$ formed the first group while the severely obese BMl>35 kg/m formed the second group. Exclusion criteria were defined as chronic renal failure, congenital anomalies of the kidney (horseshoe kidney, etc.), and patients with solitary kidneys. Age, gender, median stone burden, pre/postoperative hemoglobin $(\mathrm{Hb})$ levels, number and regions of access, duration of surgery, perioperative complications and Visual Analogue Scale (VAS) score at 24 hours, Post Anesthesia Care Unit (PACU) admission/discharge Aldrete scores, and PACU length of stay were recorded. The Aldrete score is utilized to evaluate patients to see if they can be safely discharged from the PACU (11). Patients should be scored at least 9 out of 10 to be discharged from the PACU. Additionally, the time interval between the admission and discharge from the PACU seems to be a good marker for early postoperative recovery. The stone burden was obtained by the formula lengthxwidthx $\pi \times 0.25 \mathrm{in} \mathrm{mm}^{2}$.

All surgeries were performed by the same team. Prior to the procedure, all patients were hydrated using a $20 \mathrm{mg} /$ 
$\mathrm{kg}$ saline bolus to prevent hypotension. Spinal anesthesia was performed in the sitting position using a 25 Gauge Whitacre needle at the estimated L3-4 or L4-5 interspace, and $15 \mathrm{mg}$ of hyperbaric bupivacaine was injected. Sensory block height was examined using ice, and 5 minutes after spinal anesthesia, the dermatome level was recorded. It is left to the anesthesiologist to decide whether the operation will be started or not. After spinal anesthesia induction, all patients were sedated using bolus doses of $1 \mathrm{mg}$ midazolam to reach the $2 \mathrm{mg}$ Ramsey sedation score, and the same bolus doses were used to maintain the same sedation level.

After the $6 \mathrm{Fr}$ open-ended ureteral catheter and $14 \mathrm{Fr}$ Foley catheter were placed in the lithotomy position, the patients were placed in the prone position for PNL. A fluoroscopy was used to determine access and obtain stone status during surgery. For access, a 0.038-inch guidewire was used to guide the dilation achieved through an 18 Gauge needle and Amplatz dilators (up to $30 \mathrm{Fr}$ ). The stones were visualized using a $26 \mathrm{Fr}$ nephroscope, and a pneumatic lithotripter was used for lithotripsy. Stones were removed using forceps. A 14 Fr nephrostomy tube was placed in all patients. The urethral catheter was removed, and $\mathrm{Hb}$ values were obtained on the first postoperative day. The nephrostomy tubes of the patients were removed on the second postoperative day, and the patient was discharged on the same day after observing that there was no leakage from the Access point. When patients needed analgesics on the first postoperative day, paracetamol was used initially, and tramadol was added to the treatment if sufficient pain palliation was not achieved. The total permissible doses of paracetamol and tramadol were $4 \mathrm{~g} /$ day and $400 \mathrm{mg} /$ day, respectively.
Continuous variables for statistical analysis were given as mean or median (interquartile range) when necessary. Categorical values are given as frequency or percentage. T-test, Welch T-test, and Mann Whitney $U$ tests were used for continuous variables. A chi-square test was used for categorical variables. A p value of $<0.05$ was considered statistically significant. SAS University Edition was used for statistical analysis.

Approval for this study was obtained from the Ethics Committee of Selçuk University (Date: 13.04.2017, No: 137).

\section{RESULTS}

The whole study cohort consisted of 100 patients (50 patients in both groups) with a mean age of $49.6 \pm 13.4$ years. There were 62 males (62\%) and 38 females (38\%). The mean age of patients in group 1 was $46.5 \pm 15.2$ while it was $52.2 \pm 10.8$ in group $2(p=0.02)$. Group 1 consisted of 36 males (72\%) and 14 females (28\%) whilst group 2 included 26 males (52\%) and 24 females (48\%) $(p=0.04)$ (Table 1).

Mean BMls were $22.3 \pm 2.8 \mathrm{~kg} / \mathrm{m}^{2}$ and $37.6 \pm 4.9 \mathrm{~kg} / \mathrm{m}^{2}$ in groups 1 and 2 , respectively $(p<0.001)$. The duration of surgery was $68.3 \pm 25.6$ mins in group 1 , and it was $77.5 \pm 28.6$ mins in group $2(p=0.09)$. The median stone burden of the first group was $282.3 \mathrm{~mm}^{2}$ (range 131.7-477.3 $\mathrm{mm}^{2}$ ) while the second group had a median $289.7 \mathrm{~mm}^{2}$ (range 139.3-520.9 $\left.\mathrm{mm}^{2}\right)$ stone burden $(p=0.08)$. An overview of the patient data is given in Table 1 .

Pre and postoperative $\mathrm{Hb}$ levels were similar in both groups (14.3 \pm 2.0 and $12.3 \pm 1.9$ in group $1,14.2 \pm 1.9$ and $12.2 \pm 1.8$ in group 2$)(p=0.86)$. Subcostal access was used in 45 patients $(90 \%)$ in group 1, and intercostal access

Table 1: Overview of two groups

\begin{tabular}{|c|c|c|c|}
\hline & $\begin{array}{c}\text { Group } 1 \\
\text { BMI }<35 \mathrm{~kg} / \mathrm{m}^{2}\end{array}$ & $\begin{array}{c}\text { Group } 2 \\
\text { BMI } \geq 35 \mathrm{~kg} / \mathrm{m}^{2}\end{array}$ & $p$ \\
\hline Patient number & 50 & 50 & 1 \\
\hline $\begin{array}{l}\text { Gender (\%) } \\
\text { Male } \\
\text { Female }\end{array}$ & $\begin{array}{l}36(72 \%) \\
14(28 \%)\end{array}$ & $\begin{array}{l}26(52 \%) \\
24(48 \%)\end{array}$ & 0.04 \\
\hline Mean age, year (SD) & $46.58(15,24)$ & $52.62(10.81)$ & 0.02 \\
\hline Mean BMI, kg/m² (SD) & $22.30(2,86)$ & 37.65 (4.98) & \\
\hline $\begin{array}{l}\text { Laterality, n (\%) } \\
\text { Right } \\
\text { Left }\end{array}$ & $\begin{array}{l}20(40 \%) \\
30(60 \%)\end{array}$ & $\begin{array}{l}22(44 \%) \\
28(56 \%)\end{array}$ & 0.69 \\
\hline $\begin{array}{l}\text { Access site (\%) } \\
\text { Subcostal } \\
\text { Intercostal }\end{array}$ & $\begin{array}{l}45(90 \%) \\
5(10 \%)\end{array}$ & $\begin{array}{l}39(78 \%) \\
11(22 \%)\end{array}$ & 0.1 \\
\hline Duration of surgery, $\min (S D)$ & $68.36(25,63)$ & $77.50(28.60)$ & 0.09 \\
\hline
\end{tabular}


Table 2: Postoperative parameters of patients

\begin{tabular}{|c|c|c|c|}
\hline & $\begin{array}{c}\text { Group } 1 \\
\text { BMI }<35 \mathrm{~kg} / \mathrm{m}^{2}\end{array}$ & $\begin{array}{c}\text { Group } 2 \\
\text { BMI } \geq 35 \mathrm{~kg} / \mathrm{m}^{2}\end{array}$ & p \\
\hline Time interval at the PACU, $\min (\mathrm{SD})$ & $39.04(7.54)$ & $58.48(14.06)$ & $<0.0001$ \\
\hline PACU admission Aldrete score, $n$ (SD) & $9.02(.071)$ & $8.2(0.88)$ & $<0.0001$ \\
\hline PACU discharge Aldrete score, $n$ (SD) & $9.9(0.3)$ & $9.62(0.49)$ & 0.03 \\
\hline Total Parasetamol dose, mg (Q1-Q3) & $500(0-1000)$ & $500(0-500)$ & 0.15 \\
\hline Total Tramadol dose, mg (Q1-Q3) & $100(100-200)$ & $100(0-200)$ & 0.91 \\
\hline VAS score at $24^{\text {th }}$ hour (SD) & $5.02(1.35)$ & $5.34(1.84)$ & 0.32 \\
\hline Length of hospital stay, day (SD) & $3.30(1.34)$ & $3.08(1.07)$ & 0.36 \\
\hline
\end{tabular}

was used in $5(10 \%)$ while 39 patients (78\%) in group 2 received subcostal access whereas $11(22 \%)$ received intercostal access $(p=0.1)$. VAS score at the postoperative $24^{\text {th }}$ hour was $5.0 \pm 1.3$ in group 1 while it was $5.3 \pm 1.8$ in group $2(p=0.32)$. On the other hand, the length of the hospital stay was $3.3 \pm 1.3$ days in patients with $\mathrm{BMl}<35 \mathrm{~kg} / \mathrm{m}^{2}$ and $3.0 \pm 1.0$ in patients with $B M I \geq 35 \mathrm{~kg} / \mathrm{m}^{2}(p=0.36)$.

Stone-free status was achieved in 97 patients in the study. Therefore, the overall stone-free rate (SFR) rate was $97 \%$. According to the groups, a 98\% stone-free rate was found in the severely obese group and a $96 \%$ rate in the normal BMI group, and there was no significant difference between the groups $(p=0.672)$.

PACU admission Aldrete scores showed a statistically significant difference $(9.0 \pm 0.7$ in group 1 and $8.2 \pm 0.8$ in group $2, p<0.0001)$. Also, there was a statistically significant difference in terms of PACU discharge Aldrete scores between groups $(9.9 \pm 0.3$ vs. $9.6 \pm 0.4$ in groups 1 and 2, respectively) ( $p=0.03)$. Finally, the time interval in the PACU was $39.0 \pm 7.5$ mins in group 1 while it was $58.8 \pm 14.0$ mins in group $2(p<0.0001)$.

In regards to the analgesic dose required, the mean paracetamol and tramadol use in the first 24 hours was $500 \mathrm{mg}(0-1000)$ and $100 \mathrm{mg}(100-200)$, respectively in group 1 where it was $500 \mathrm{mg}(0-500)$ and $100 \mathrm{mg} \mathrm{(0-200)}$ in group 2 . There was no statistically significant difference between the groups $(p=0.15$ and 0.91 for paracetamol and tramadol, respectively). Table 2 gives a summary of the postoperative findings.

\section{DISCUSSION}

To our knowledge, there is inadequately published literature on the use of regional anesthesia in obese patients who are undergoing PNL. This forms the basis of our current study.

In obese patients, anesthetic, surgical techniques, and pre-surgical problems can be challenging for urologists
(12). Excessive fat tissue decreases the image quality of fluoroscopy screening and reduces the accuracy of defining the appropriate calyx or stone during access. Additionally, identifying a landmark at the beginning of the operation is complicated in obese patients. Also, accessing the pelvicalyceal system and dilating the tract is more challenging. Additionally, an adequate length of a working sheath and working instruments in obese patients has adverse effects on PNL outcomes $(13,14)$.

PNL was originally performed under general anesthesia (15). Particularly in obese patients, with general anesthesia, there is a risk of tube displacement during change of position from supine to prone, and this carries a higher risk of pulmonary complications, such as reduction in total lung capacity, expiratory lung volume, and functional residual capacity (16). For this reason, a PNL operation was performed in some centers in a supine position instead of a prone position, and it was shown that the operation time was shorter while stone-free, complication, blood transfusion, and postoperative fever rates were similar $(17,18)$.

Spinal anesthesia generally has a less side effect profile than general anesthesia and is a more economical method $(19,20)$. Also, the ability to easily change the patient's position during anesthesia is another advantage of spinal anesthesia.

The first description of PNL with regional anesthesia was reported in 1988. The authors evaluated 112 patients who underwent PNL with epidural anesthesia. The authors reported that when compared with local anesthesia associated with sedative analgesia or general anesthesia, epidural anesthesia appeared to be more convenient (21).

Various studies reported comparatively similar results in obese patients in terms of the duration of surgery, the length of the hospital stay, and the $\mathrm{Hb}$ drop, in addition to a global study that looked at 5803 patients with different BMI groups and revealed only a longer duration of surgery in morbidly obese patients (22-24). In a recent meta-analysis, PNL in obese patients was shown to have 
similar surgical outcomes compared with non-obese counterparts, along with shorter lengths of hospital stays (2). In the study by Kuzgunbay et al. comparing the PNL operations performed under spinal and general anesthesia, they found no statistically significant difference between the two groups in terms of stone-free and complications (16).

Our results show similar results for PNL under spinal anesthesia with no statistically significant differences between the two groups in terms of duration of surgery, $\mathrm{Hb}$ drop, and the length of hospital stay. Furthermore, our results indicate there is no difference in mean analgesic use in obese patients, which is in accordance with previous studies.

Another aspect of surgery that should be taken into account is the recovery period. Patients are transferred to PACU after extubating and stay there until they become fit for discharge to their rooms. The Aldrete scoring system is the most widely used clinical tool to assess the physical status of patients recovering from anesthesia (26). Patients need to have at least 9 points out of 10 for a safe discharge. In a study comparing general anesthesia and segmental epidural anesthesia for PNL, the time it took to reach Aldrete's score of 9 was $27.2 \pm 5.6$ for general anesthesia and $10.4 \pm 4.1$ for segmental epidural anesthesia. The mean BMI of the study cohort was 22 $\mathrm{kg} / \mathrm{m}^{2}$ with no statistical difference between groups (27). Our results revealed a lower PACU admission Aldrete score, a lower PACU discharge score, and a longer interval in PACU for patients with $\mathrm{BMI} \geq 35 \mathrm{~kg} / \mathrm{m}^{2}$. Therefore, severely obese patients may be informed that it would take a longer time for them to be brought back to their rooms. Moreover, the result of our study showed VAS scores at the postoperative $24^{\text {th }}$ hour are similar in the two groups.

The main limitation of our prospective study is the relatively small number of patients. In addition, age groups were not statistically similar even though the difference between means of the groups is 6 years. We believe that this is a consequence of the peak incidence of obesity, which is observed between 55-65 years of age (28). Also, females were statistically more frequent in group 2 which is possibly a result of female predominance in obesity in the world, as well as in our country (29).

\section{CONCLUSION}

Severe obesity does not alter surgical outcomes in patients undergoing PNL under spinal anesthesia, and in our opinion, spinal anesthesia in PNL is a safe and effective anesthesia modality for renal stone(s) in obese and morbidly obese patients. The role of spinal anesthesia must be investigated by further prospective, randomized studies with larger patient volumes.
Ethics Committee Approval: This study was approved by the Selcuk University, Non-Interventional Clinical Research Ethics Committee (Date: 13.04.2017, No: 137).

Informed Consent: Written consent was obtained from the participants.

Peer Review: Externally peer-reviewed.

Author Contributions: Conception/Design of Study- A.Ö.H. B.B.; Data Acquisition- A.Ö.H., M.G., Ö.E.A.; Data Analysis/lnterpretation- A.Ö.H., M.I.D.; Drafting Manuscript- A.Ö.H., B.B., M.I.D.; Critical Revision of Manuscript- A.Ö.H., M.G., Ö.E.A.; Approval and Accountability- A.Ö.H., M.I.D., M.G., Ö.E.A., B.B.

Conflict of Interest: Authors declared no conflict of interest.

Financial Disclosure: Authors declared no financial support.

Etik Komite Onayı: Bu çalışma için etik komite onayı Selçuk Üniversitesi, Girişimsel Olmayan Klinik Araştırmalar Etik Kurulu'ndan alınmıştır (Tarih: 13.04.2017, No: 137).

Bilgilendirilmiş Onam: Katılımcılardan bilgilendirilmiş onam alınmıştır.

Hakem Değerlendirmesi: Dış bağımsız.

Yazar Katkıları: Çalışma Konsepti/Tasarım- A.Ö.H., B.B.; Veri Toplama-A.Ö.H., M.G., Ö.E.A.; Veri Analizi/Yorumlama- A.Ö.H., M.i.D.; Yazı Taslağı- A.Ö.H., B.B., M.i.D.; İçeriğin Eleştirel İncelemesi- A.Ö.H., M.G., Ö.E.A.; Son Onay ve Sorumluluk- A.Ö.H., M.I.D., M.G., Ö.E.A., B.B.

Çıkar Çatışması: Yazarlar çıkar çatışması beyan etmemişlerdir.

Finansal Destek: Yazarlar finansal destek beyan etmemişlerdir.

\section{REFERENCES}

1. Keheila M, Leavitt D, Galli R, Motamedinia P, Theckumparampil N, Siev $M$, et al. Percutaneous nephrolithotomy in super obese patients (body mass index $\left.\geq 50 \mathrm{~kg} / \mathrm{m}^{2}\right)$ : overcoming the challenges. BJU Int 2016;117(2):300-6. [CrossRef]

2. Zhou X, Sun X, Chen X, Gong X, Yang Y, Chen C, et al. Effect of Obesity on Outcomes of Percutaneous Nephrolithotomy in Renal Stone Management: A Systematic Review and Meta-Analysis. Urol Int 2017;98(4):382-90. [CrossRef]

3. Scales CD Jr, Smith AC, Hanley JM, Saigal CS. Urologic Diseases in America Project. Prevalence of kidney stones in the United States. Eur Urol 2012;62(1):160-5. [CrossRef]

4. Ozgor F, Ucpinar B, Binbay M. Effect of Obesity on Prone Percutaneous Nephrolithotomy Outcomes: A Systemic Review. Urol J 2016;13(1):2471-8. PMID: 26945649.

5. Pareek G, Hedican SP, Lee FT Jr, Nakada SY. Shock wave lithotripsy success determined by skin-to-stone distance on computed tomography. Urology 2005;66(5):941-4. [CrossRef] 
6. Doizi S, Letendre J, Bonneau C, Gil Diez de Medina S, Traxer O. Comparative study of the treatment of renal stones with flexible ureterorenoscopy in normal weight, obese, and morbidly obese patients. Urology 2015;85(1):3844. [CrossRef]

7. Sari E, Tepeler A, Yuruk E, Resorlu B, Akman T, Binbay $M$, et al. Effect of the body mass index on outcomes of flexible ureterorenoscopy. Urolithiasis 2013;41(6):499-504. [CrossRef]

8. Ramakumar S, Segura JW. Renal calculi. Percutaneous management. Urol Clin North Am 2000;27(4):617-22. [CrossRef]

9. Nouralizadeh A, Ziaee SA, Hosseini Sharifi SH, Basiri A, Tabibi A, Sharifiaghdas F. et al. Comparison of percutaneous nephrolithotomy under spinal versus general anesthesia: a randomized clinical trial. J Endourol 2013;27(8):974-8. [CrossRef]

10. Singh V, Sinha RJ, Sankhwar SN, Malik A. A prospective randomized study comparing percutaneous nephrolithotomy under combined spinal-epidural anesthesia with percutaneous nephrolithotomy under general anesthesia. Urol Int 2011;87(3):293-8. [CrossRef]

11. Aldrete JA. The post-anesthesia recovery score revisited. J Clin Anesth 1995;7(1):89-91. [CrossRef]

12. Wu SD, Yilmaz M, Tamul PC, Meeks JJ, Nadler RB. Awake endotracheal intubation and prone patient selfpositioning: anesthetic and positioning considerations during percutaneous nephrolithotomy in obese patients. J Endourol 2009;23(10):1599-602. [CrossRef]

13. Gofrit ON, Shapiro A, Donchin Y, Bloom Al, Shenfeld OZ, Landau EH. et al. Lateral decubitus position for percutaneous nephrolithotripsy in the morbidly obese or kyphotic patient. J Endourol 2002;16(6):383-6. [CrossRef]

14. Nguyen TA, Belis JA. Endoscopic management of urolithiasis in the morbidly obese patient. J Endourol 1998; 12(1):33-5. [CrossRef]

15. Basiri A, Kashi AH, Zeinali M, Nasiri MR, Valipour R, Sarhangnejad R. Limitations of Spinal Anesthesia for Patient and Surgeon During Percutaneous Nephrolithotomy. Urol J 2018;15(4):164-7. [CrossRef]

16. Kuzgunbay B, Turunc T, Akin S, Ergenoglu P, Aribogan A, Ozkardes H. Percutaneous nephrolithotomy under general versus combined spinal-epidural anesthesia. J Endourol 2009;23(11):1835-8. [CrossRef]

17. Mazzucchi E, Vicentini FC, Marchini GS, Danilovic A, Brito $\mathrm{AH}$, Srougi M. Percutaneous nephrolithotomy in obese patients: comparison between the prone and total supine position. J Endourol 2012;26(11):1437-42. [CrossRef]

18. Liu L, Zheng $S, X u Y$, Wei $Q$. Systematic review and metaanalysis of percutaneous nephrolithotomy for patients in the supine versus prone position. J Endourol 2010;24(12):19416. [CrossRef]
19. Borendal Wodlin N, Nilsson L, Carlsson P, Kjølhede P. Costeffectiveness of general anesthesia vs spinal anesthesia in fast-track abdominal benign hysterectomy. Am J Obstet Gynecol 2011;205(4):326.e1-7. [CrossRef]

20. McLain RF, Kalfas I, Bell GR, Tetzlaff JE, Yoon HJ, Rana M. Comparison of spinal and general anesthesia in lumbar laminectomy surgery: a case-controlled analysis of 400 patients. J Neurosurg Spine 2005;2(1):17-22. [CrossRef]

21. Ballestrazzi V, Zboralski C, Smith-Morel P, Boullet $M$, Willot I,Hochart D. et al. Intérêt de l'anesthésie péridurale suspendue dans la néphrolithotomie percutanée. A propos de 112 patients du service des voies urinaires du C.H.R. de Lille [Importance of suspended peridural anesthesia in percutaneous nephrolithotomy. Apropos of 112 patients in the urology service of the Regional Hospital Center of Lille]. Cah Anesthesiol 1988;36(2):85-8. French. PMID: 3365593.

22. Koo BC, Burtt G, Burgess NA. Percutaneous stone surgery in the obese: outcome stratified according to body mass index. BJU Int 2004;93(9):1296-9. [CrossRef]

23. El-Assmy AM, Shokeir AA, El-Nahas AR, Shoma AM, Eraky I,El-Kenawy MR. et al. Outcome of percutaneous nephrolithotomy: effect of body mass index. Eur Urol 2007;52(1):199-204. [CrossRef]

24. Fuller A, Razvi H, Denstedt JD, Nott L, Pearle M, Cauda F. et al: CROES PCNL Study Group. The CROES percutaneous nephrolithotomy global study: the influence of body mass index on outcome. J Urol 2012;188(1):138-44. [CrossRef]

25. Shohab D, Ayub R, Alam MU, Butt A, Sheikh S, Assad S. et al. Effect of body mass index on operative time, hospital stay, stone clearance, postoperative complications, and postoperative analgesic requirement in patients undergoing percutaneous nephrolithotomy. Turk J Urol 2015;41(4):177-80. [CrossRef]

26. Phillips NM, Street M, Kent B, Haesler E, Cadeddu M. Postanaesthetic discharge scoring criteria: key findings from a systematic review. Int J Evid Based Healthc 2013;11(4):27584. [CrossRef]

27. Parikh DA, Patkar GA, Ganvir MS, Sawant A, Tendolkar BA. Is segmental epidural anaesthesia an optimal technique for patients undergoing percutaneous nephrolithotomy? Indian J Anaesth 2017;61(4):308-314. [CrossRef]

28. Satman I, Omer B, Tutuncu Y, Kalaca S, Gedik S, Dinccag N. et al. TURDEP-II Study Group. Twelve-year trends in the prevalence and risk factors of diabetes and prediabetes in Turkish adults. Eur J Epidemiol 2013;28(2):169-80. [CrossRef]

29. NCD Risk Factor Collaboration (NCD-RisC). Trends in adult body-mass index in 200 countries from 1975 to 2014: a pooled analysis of 1698 population-based measurement studies with 19.2 million participants. Lancet 2016;387(10026):1377-96. [CrossRef] 